УДК631.8:631.547.1:633.13

(C) 2016

Гончар Л. М., кандидат сільськогосподарських наук

Національний університет біоресурсів і природокористування України

\title{
ДІЯ КОЛОЇДНОГО РОЗЧИНУ МІДІ ТА ЦИНКУ НА ПРОРОСТАННЯ НАСІННЯ ВІВСА
}

\section{Рецензент - кандидат сільськогосподарських наук В. М. Рожко}

У статті наведено результати впливу колоїдного розчину різної концентрації циинку $i$ міді та їхнього комплексу на лабораторну схожість насіння вівса. Встановлено, щзо дія концентращиї міді 1:1 є фітотоксичною під час пророщування насіння вівса. Зазначено, щзо за концентрації міді $1: 1$ знижується схожість насіння на 3-14\%, щуо має негативний вплив у подальших ростових процесах вівса. Встановлено, щзо кониентрація міді 1:10 впливає на схожість насіння на рівні контрольного варіанту, тобто не прослідковується фітотоксичність даної концентрації розчину міді. Це веде до резонності використання даної концентрації розчину. Відзначено, щз за конщентраuүiі міді 1:100 схожість насіння усіх досліджуваних культур підвищилась, щзо дає змогу стверджувати про ефективність розчину за даної концентрації. Встановлено, шуо насіння вівса знизило схожість за концентрації цинку 1:1 i 1:10, лише за концентрації 1:100 спостерігали зростання відсотку схожих насінин.

Ключові слова: овес, насіння, колоїдний розчин міді та ицинку, концеентрація, фітотоксичність.

Постановка проблеми. Однією 3 актуальних проблем сьогодення $\epsilon$ істотне антропогенне забруднення довкілля, яке чинить вплив на насіння i рослини. Особливої уваги заслуговує такий клас полютантів, як важкі метали [6]. Завдяки присутності доступних мікроелементів, у насінні максимально активізуються ферментативні процеси [2]. Обробляння насіння перед сівбою стимулюючими ріст препаратами забезпечує швидке і дружнє проростання, збільшує стійкість рослин до таких несприятливих факторів, як нестача вологи та ураження хворобами, значно покращує конкурентні властивості культурних рослин стосовно бур'янів [7].

Аналіз останніх досліджень і публікацій, у яких започатковано розв'язання проблеми. Між нагромадженням важких металів у рослинах i забрудненням середовища є прямий, хоча i непропорційний зв'язок: чим вища концентрація металів у середовищі, тим більше їх у рослинах [7]. Забруднення сільськогосподарських угідь важкими металами в основному відбувається за рахунок атмосферних викидів підприємств, від- ходів тваринницьких ферм і внаслідок застосування мінеральних добрив і отрутохімікатів [4, 6]. Органічні добрива (гній і компост) також містять значну кількість важких металів; у результаті внесення у грунт органіки в ньому зростає концентрація таких хімічних елементів, як Плюмбум, Кадмій, Купрум, Цинк, Ферум, Манган [7]. Враховуючи повільне виведення важких металів із грунту, за тривалого надходження навіть відносно невеликих кількостей Кадмію і Плюмбуму, їхня концентрація 3 часом може досягати досить високих значень $[2,7]$.

Водночас деякі важкі метали у мінімальних кількостях необхідні для здійснення біохімічних i фізіологічних процесів у рослинах. За нестачі цих металів порушується ріст і розвиток рослин [1]. У природних умовах у грунтах одночасно наявні різні метали. Деякі з них взаємодіють між собою. Дані, наявні в науковій літературі, стосуються реакції-відповіді рослин на дію окремих (понад двадцять) різних металів, які по-різному нагромаджуються в органах рослин і впливають на їхній ріст і розвиток $[4,5]$. Для цих досліджень важливо встановити, як розподіляються важкі метали в різних органах, тканинах, клітинах i органелах. Дослідження ростових процесів рослин за дії важких металів, встановлення механізмів стійкості рослин і акумулювання важких металів - актуальне завдання сучасної біології рослин [5].

Цинк впливає на ріст рослин через його участь у синтезі ауксинів (гормонів росту). Нестача цинку пригнічує швидкість поділу клітин, що призводить до зовнішніх змін [1].

Кількість міді в момент проростання корінців рослини зменшується і відновлюється тільки за переходу на самостійне живлення. Тому рослини найбільш сприйнятливі до підживлення міддю на початковому етапі розвитку. Насіння, оброблене міддю, випереджає за темпами росту контрольні на $20 \%$. У результаті рослини виявляються більш стійкими до перепадів температур і легше переносять грунтову посуху. В разі внесення високих доз азотних добрив підсилюється 
потреба рослин у міді, що також сприяє загостренню симптомів мідної недостатності [5].

Вагоме значення для отримання високої продуктивності зернових злакових культур має інтенсивність початкових процесів росту. Один із заходів, що дає змогу вирішити задачу - підбір оптимального комплексу для обробляння насіннєвого матеріалу 3 використанням мікроелементів і бактеризації перед сівбою, що $є$ основою для отримання здорових, дружніх сходів і сприяє покращанню посівних якостей насіння [1].

Насіння зернових злакових культур порівняно швидко набубнявіє у грунті та для проростання потребує води 50-60 \% від своєї маси. За недостатньої вологи насіння перебуває у стані вимушеного спокою, відсутність кисню у грунті теж негативно впливає на процес проростання насіння. За достатньої вологи та сприятливих умов метаболітичні процеси у насінні активуються, зростає інтенсивність дихання, що є показником проростання насіння [1, 5].

Від схожості насіння залежить густота посіву і рівномірність розподілу стеблостою. Схожість насіння формується у процесі вирощування i значною мірою залежить від грунтовокліматичних умов, технології вирощування, передпосівного обробляння насіння [1].

Насіння $з$ високою лабораторною схожістю не завжди дає дружні повноцінні сходи у польових умовах. Низька польова схожість насіння $\epsilon$ причиною не тільки зрідження, а й ослаблення сходів, що призводить до зниження врожайності рослин [5].

У зв'язку із викладеним метою нашої роботи було дослідити вплив колоїдного розчину різної концентрації цинку і міді та їхньої комплексної дії на лабораторну схожість насіння вівса.

Головним завданням є забезпечення максимальної урожайності сільськогосподарських культур, фундаментом якої є насіннєвий матеріал.

Матеріал і методика досліджень. Досліджували рослини вівса (Avena L.) сорту Бусол. Насіння пророщували на дистильованій воді (контроль) та на колоїдному розчині $\mathrm{Zn} \mathrm{i} \mathrm{Cu}$ з концентрацією $1: 1 ; 1: 10$ та 1:100. Дослідження проводили у трьох повторностях.

Основний показник якості цього матеріалу $є$ схожість насіння, що значною мірою і забезпечує реалізацію біопотенціалу культурних рослин. Від схожості насіння залежить густота посіву i рівномірність розподілу стеблостою. Схожість насіння формується у процесі вирощування i значною мірою залежить від грунтовокліматичних умов, технології вирощування, пе- редпосівного обробляння насіння. Схожість насіння (лабораторна) - це відношення кількості пророслого насіння зернових культур до кількості висіяного, що визначається в лабораторних умовах, виражене у відсотках.

Насіння обробляли згідно з наведеною схемою:

Контроль (дистильована вода); 2. Zn у концентрації $1: 1 ; 3$. Cu у концентрації $1: 1 ; 4$. Zn у концентрації $1: 10 ; 5 . \mathrm{Cu}$ у концентрації $1: 10 ; 6$. Zn у концентрації 1:100; 7. Cu у концентрації 1:100.

Науковцями НУБіП України (К. Г. Лопатько, Є. Г. Афтанділянц, Д. А. Засекін, С. М. Каленська, О. Л. Тонха) розроблена технологія отримання фізичним методом колоїдних розчинів біогенних металів на водній основі, таких як $\mathrm{Fe}, \mathrm{Mn}, \mathrm{Zn}$, $\mathrm{Mo}, \mathrm{Co}, \mathrm{Cu}, \mathrm{Ag}$, які необхідні рослинам для реалізації біологічного потенціалу та запатентовано маточний колоїдний розчин вищезазначених металів [3].

Результати досліджень. Предметом дослідження було обрано насіння вівса сорту Бусол. За проростання насіння вівса вбирає 60-65 \% води від власної маси. Застосування колоїдного розчину $\mathrm{Cu}$ за концентрації 1:1 насіння вівса через 3 доби не проросло (рис. 1). Спостерігали поодиноке прокльовування насіння. Тобто було масове пригнічення процесу проростання насіння за концентрації $\mathrm{Cu} 1: 1$, що призвело до зниження схожості насіння.

Застосування колоїдного розчину $\mathrm{Zn}$ на проростання насіння вівса мало позитивний вплив, що у результаті підвищило відсоток схожих насінин. Проведені дослідження показали, що обробляння насіння розчинами різних концентрацій Zn мало вплив на проростання насіння вже на початкових етапах онтогенезу. Проростки 3'являлися у чашці Петрі з концентрацією 1:10 на четверту добу експерименту (рис. 2).

У контролі в цей час насіння тільки набубнявіло i почало проростати. Проростки характеризувалися значно більшими показниками, порівняно 3 контролем та іншими варіантами.

Проаналізувавши отримані результати пророщування та обрахувавши схожість насіння вівса, було встановлено, що концентрація міді $1: 1$ є фітотоксичною під час проростання вівса.

Визначено, що концентрація міді 1:1 знижує схожість насіння на 3-14\% (рис. 3), що є негативним у подальшому вирощуванні вівса. Так як зі зменшенням лабораторної схожості зменшується і польова, це веде до зрідженості посівів даних культур. 
СІЛЬСЬКЕ ГОСПОДАРСТВО. РОСЛИННИЦТВО

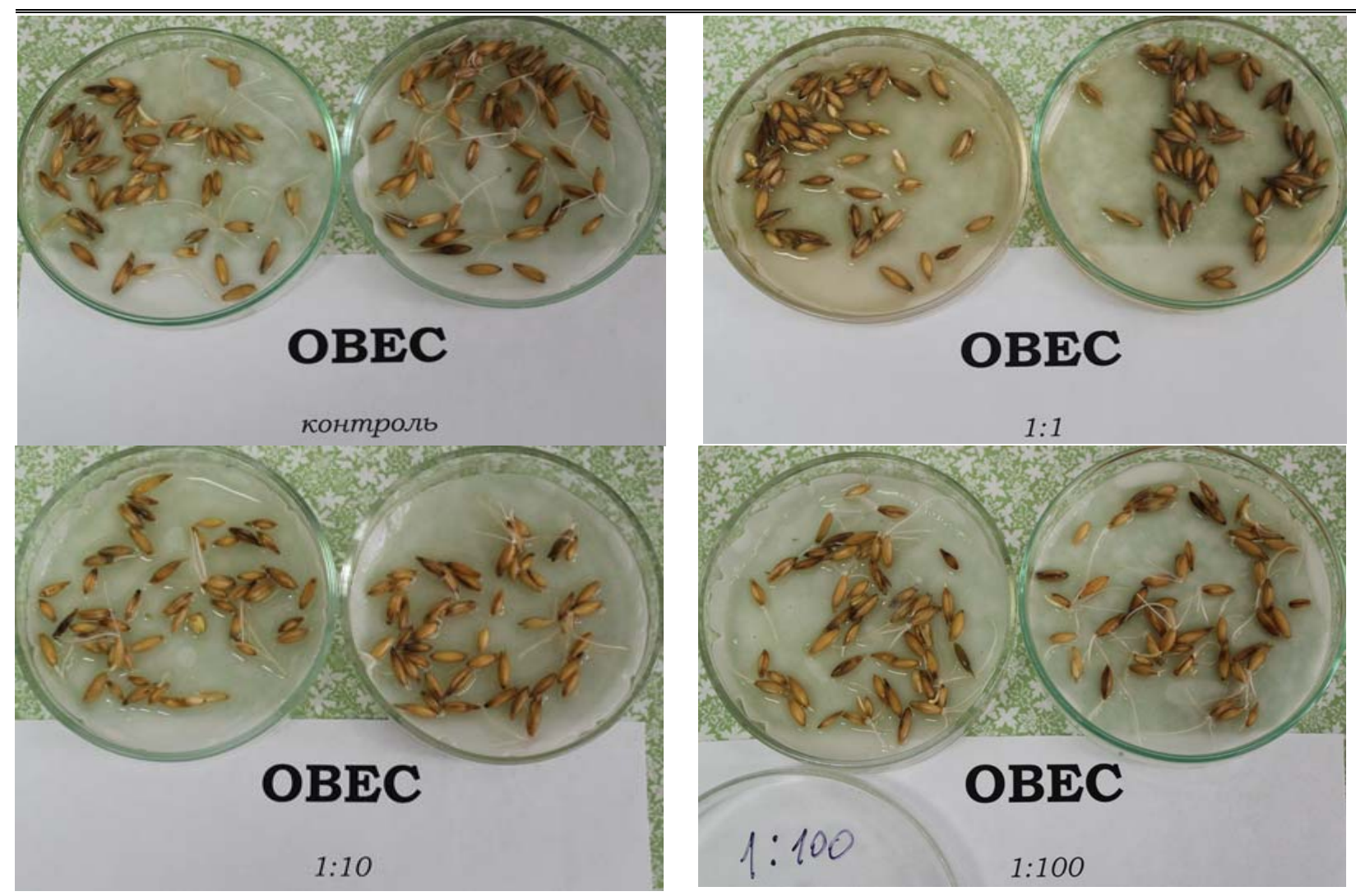

Рис. 1. Вплив на пророщування насіння вівса сорту Бусол колоӥдного розчину Си, через 3 доби
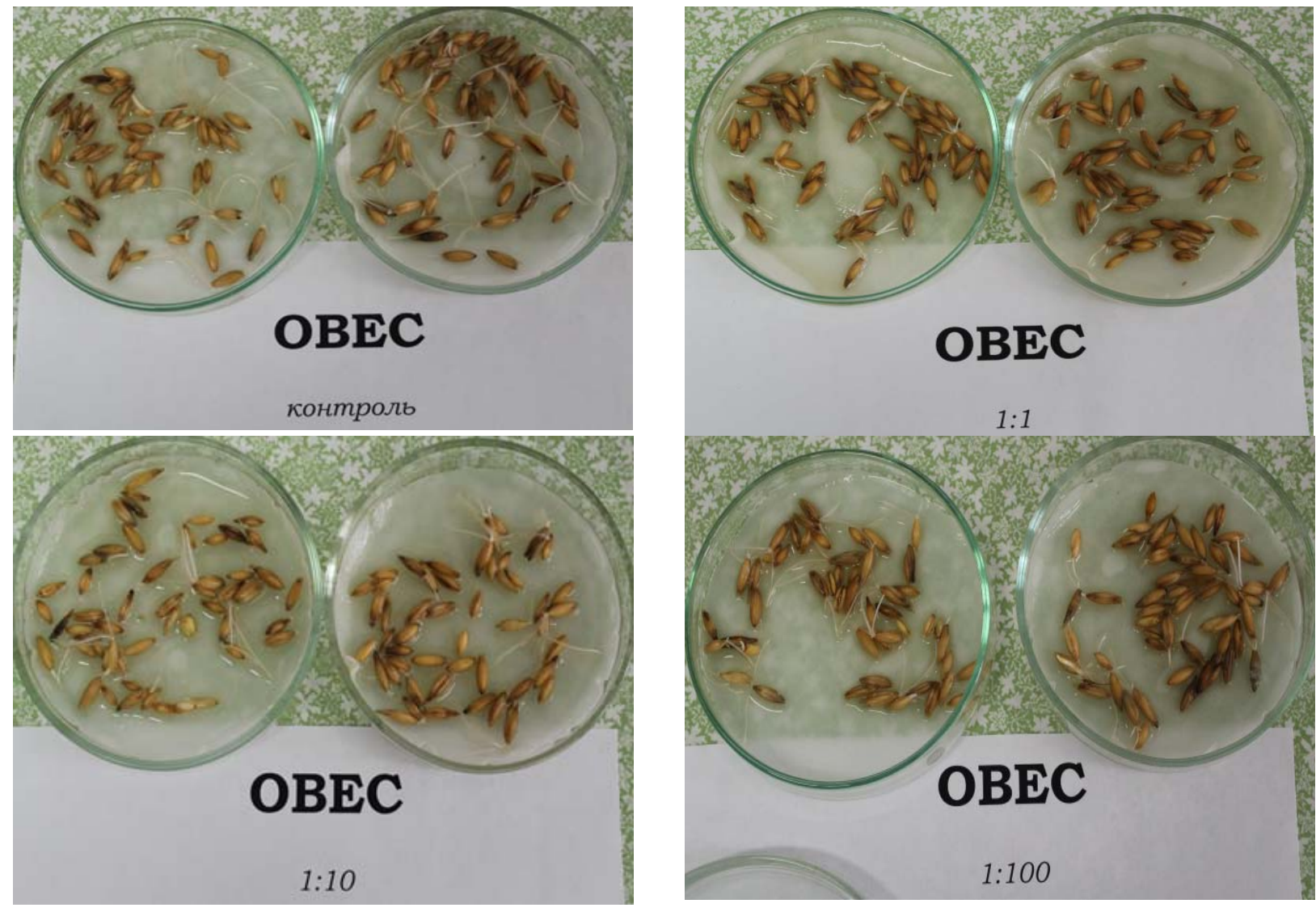

Рис. 2. Вилив на пророщування насіння вівса сорту Бусол колоӥдного розчину $\mathrm{Zn}$, через 3 доби 


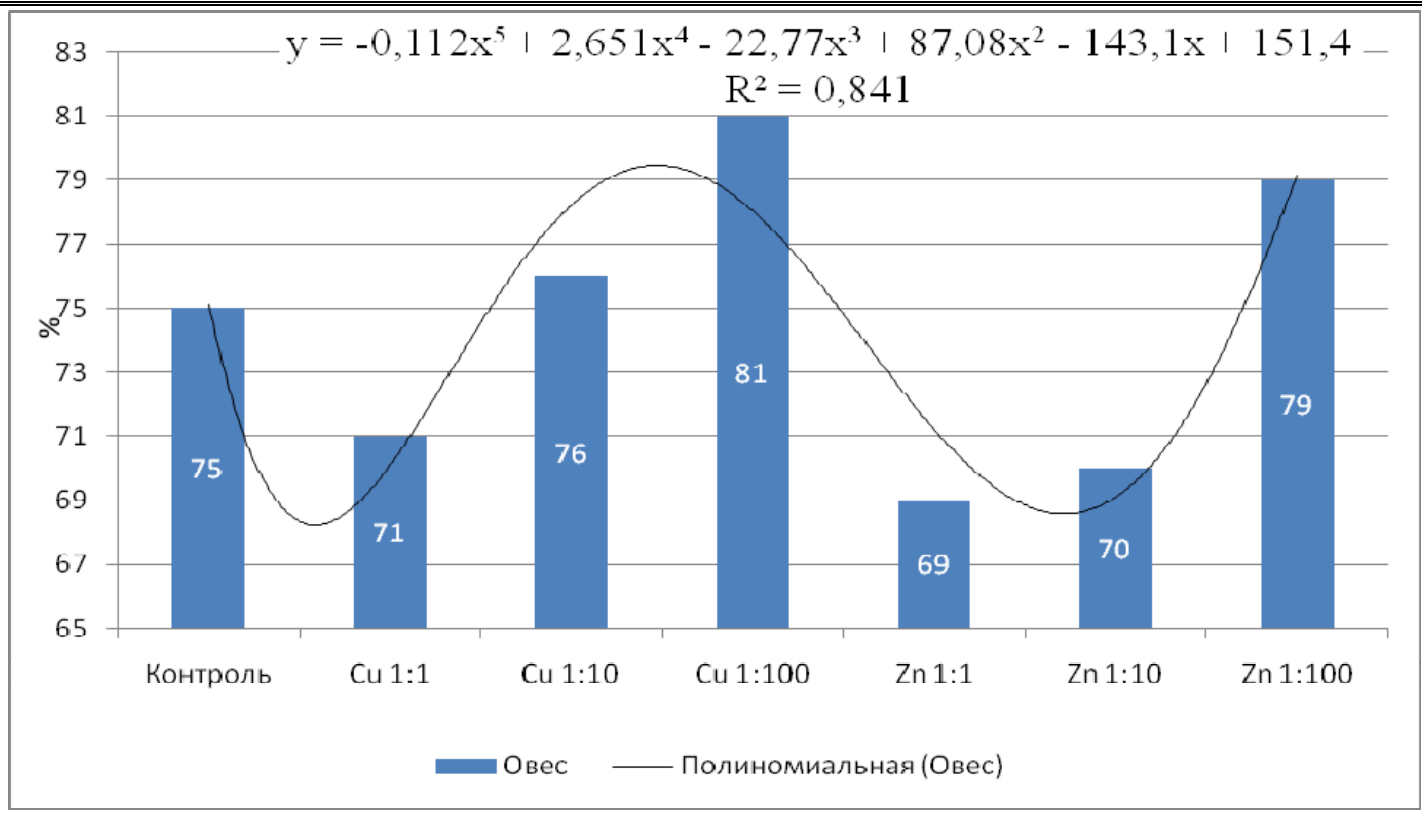

Рис. 3. Схожість насіння зернових культур залежно від досліджуваного компоненту, \%

Потрібно зазначити, що зі зменшенням концентрації колоїдного розчину міді та цинку зростала лабораторна схожість, про що свідчать отримані дані відповідно $81 \%$ та 79 \% порівняно 3 контрольним варіантом $75 \%$.

Встановлено тісну кореляційну залежність між концентрацією колоїдного розчину та лабораторною схожістю, яка становить $\mathrm{R}=0,841$ та отримано регресійне рівняння

$\mathrm{y}=-0,1125 \mathrm{x}^{5}+2,6515 \mathrm{x}^{4}-22,778 \mathrm{x}^{3}+87,083 \mathrm{x}^{2}-$ $143,12 x+151,43$.

За концентрації міді 1:10 схожість насіння знаходиться на рівні контрольних показників, тобто не прослідковується фітотоксичність розчину, але й введення даного компоненту немає підстав.

Варто зазначити, що за концентрації міді 1:100 схожість насіння досліджуваної культури

\section{БІБЛІОГРАФІЯ}

1. Гончар Л. Н. Применение наноразмерных биогенных металлов в технологии выращивания пшеницы озимой в условиях Правобережной Лесостепи Украины / Л. Н. Гончар // Технические науки - от теории к практике. - АНС «СибАК».2013. - №26. - C. 25-27.

2. Нанотехнологии в сельском хозяйстве / [Каплуненко В. Г., Косинов Н. В., Бовсуновский А. Н., Черный С. А.] // Зерно. - №4 (25). 2008. - С. 47-54.

3. Патент № 38459 від 12.01.2009 / [Лопатько К. Г., Афтанділянц Є. Г., Каленська С. М., Тонха О. Л.].

4. Рыбалкина М. Нанотехнологии для всех / М. Рыбалкина. - M. : Nanotechnology News зросла, що дає змогу стверджувати про ефективність даного розчину за даної концентрації.

Встановлено, що насіння вівса знизило схожість за концентрації цинку $1: 1$ і 1:10, лише за концентрації 1:100 спостерігали зростання відсотку схожих насінин.

Висновок. Обробляння посівного матеріалу колоїдним розчином нанометалів підвищує польову схожість насіння в залежності від потенціалу сорту та за низької концентрації колоїдного розчину є важливим.

Захищає насіння та сходи від інфекції, дає змогу не тільки заощадити $50 \%$ протруювача, а й повністю його замінити без погіршення якості передпосівного обробляння насіння, проявляє синергетичну дію, виключає осипання протруювача під час транспортування, завантаження та сівби.

Network, 2005. - $444 \mathrm{c}$.

5. Франтійчук $B$. В. Вплив неіонного колоїдного розчину наночасток металів на ріст і розвиток озимої пшениці / В. В. Франтійчук, М. С. Коваленко, Л. М. Гончар та ін. // Збірник наукових праць Інституту біоенергетичних культур і цукрових буряків. - 2012. - №14. - С. 119-123.

6. Lin D. Phytotoxicity: of Nanoparticles: inhibition of seed germination and root growth, Environ / D. Lin, B. Xing // Pollut. - 2007. - №150. P. 243-250.

7. Sozer N. Nanotechnology and its applications in the food sector / N. Sozer, J. L. Kokini // Trends Biotechnol. -2009. - 27. - P. 82-89. 